\title{
Sensing Change: On Adding a Psychological Touch of Grit to Conventional Medical School Selection Criteria [Letter]
}

This article was published in the following Dove Press journal: Advances in Medical Education and Practice

\author{
Syeda Zoha Zehra Rizvi (iD \\ Syeda Sakina Zehra $\mathbb{D D}^{2}$ \\ 'Jinnah Sindh Medical University, Karachi, \\ Pakistan; ${ }^{2}$ Karachi Medical and Dental \\ College, Karachi, Pakistan
}

\section{Dear editor}

We have read the paper entitled "Effects of Grit on the Academic Performance of Medical Students" by Alzerwi ${ }^{1}$ published in Advances in Medical Education and Practice. We congratulate and thank the author for bringing this issue, and followup to the article.

The data for this study were collected when the students were beginning their academic year, and also because this study is a cross-sectional study, the participants referred to their previous year's activities in the survey. Hence, the question arises of whether their current grit scores has affected their performance or the activities left them with their current grit scores. Therefore, based on this study it is uncertain to use grit scores in predicting especially the academic properties of the participants.

Grit scores can also secondarily predict other important outcomes ${ }^{2}$ like passion and aim for pursuing medicine in the future. This can help in addressing an important issue of abandonment of practice by female graduates, influenced by family pressure, in Pakistan, ${ }^{3}$ and also reduce the number of drop-outs by enrolling only the most dedicated applicants.

The author did not brief about the questions he used in the questionnaire to illustrate how he matched perseverance and distraction to grit. Moreover, questions about aspired specialty could also be included in the survey because the specialties do give an idea about the resilience of the applicants.

Saudi Arabia is a male-dominant country with under-representation of females in the workforce, requiring them to be more resilient to achieve the desired positions in the society, can also be attributed to the results highlighted in this study of females proving to be grittier than their male counterparts even though they showed less research participation.

While noticing that the p-value given in this article when the author compared grit scores with age was $\mathrm{p}=0.22$, the author having found no significant correlation between the two, we went on to seek the literature and found that Pena and Duckworth $^{4}$ in their study have identified a positive relationship between absolute age and grit-perseverance subscale with a $p$-value of $p<0.001$.

The author discussed the reason for lower academic performance and higher repeat status of clinical students being summative assessments that are more
Correspondence: Syeda Zoha Zehra Rizvi Jinnah Sindh Medical University, B-349, Block 6, Gulshan-e-lqbal, Karachi,

Pakistan

Tel +923342721995

Email syedazohazehra@gmail.com
Advances in Medical Education and Practice 2020:1 I 525-526 
demanding towards an individual student. Furthermore, we have found evidence that experiencing death takes an emotional toll on the students ${ }^{5}$ besides the exhaustion they face due to wards-rotation. We suggest studies conducted that relate this emotional toll and exhaustion with Grade-Point-Average and repeat status of clinical students.

Since an inverse relationship between research participation and GPA has been proposed by the author, we endorse these variables to be taken separately from each other to check for their independent effects on the grit scores.

In conclusion, we are looking forward to more focused studies and more inclusive studies in terms of variables, involving grit because these studies can be attributed to many factors in a medical career and can have extensive applications.

\section{Disclosure}

The author reports no conflicts of interest in this communication.

\section{References}

1. Alzerwi NAN. Effects of grit on the academic performance of medical students: a Cross-Sectional Study at Majmaah University. Adv Med Educ Pract. 2020;11:419-425. doi:10.2147/AMEP.S256152

2. Miller-Matero LR, Martinez S, MacLean L, Yaremchuk K, Ko AB. Grit: a predictor of medical student performance. Educ Health. 2018;31(2):109-113. doi:10.4103/efh.EfH_152_16

3. Moazam F, Shekhani S. Why women go to medical college but fail to practise medicine: perspectives from the Islamic Republic of Pakistan. Med Educ. 2018;52(7):705-715. doi:10.1111/medu.13545

4. Peña PA, Duckworth AL. The effects of relative and absolute age in the measurement of grit from 9th to 12th grade. Econ Educ Rev. 2018;66:183-190. doi:10.1016/j.econedurev.2018.08.009

5. Jacoby LH, Beehler CJ, Balint JA. The impact of a clinical rotation in hospice: medical students' perspectives. J Palliat Med. 2011;14 (1):59-64. doi:10.1089/jpm.2010.0281

Dove Medical Press encourages responsible, free and frank academic debate. The content of the Advances in Medical Education and Practice 'letters to the editor' section does not necessarily represent the views of Dove Medical Press, its officers, agents, employees, related entities or the Advances in Medical Education and Practice editors. While all reasonable steps have been taken to confirm the content of each letter, Dove Medical Press accepts no liability in respect of the content of any letter, nor is it responsible for the content and accuracy of any letter to the editor.

\section{Publish your work in this journal}

Advances in Medical Education and Practice is an international, peerreviewed, open access journal that aims to present and publish research on Medical Education covering medical, dental, nursing and allied health care professional education. The journal covers undergraduate education, postgraduate training and continuing medical education including emerging trends and innovative models linking education, research, and health care services. The manuscript management system is completely online and includes a very quick and fair peer-review system. Visit http://www.dovepress.com/testimonials.php to read real quotes from published authors. 